\title{
New evidence of parasitoids of pest aphids on roses and grapevine in Turkey (Hem., Aphididae; Hym., Braconidae, Aphidiinae)
}

\begin{abstract}
Aphidius eglanteriae as a parasitoid of Chaetosiphon tetrarhodum/ Rosa is newly recorded for Turkey. Short information about its parasitism rate and distribution in Isparta Province, Turkey, is given. Another new information pertains to the association between Aphidius matricariae - Aphis illinoisensis - Vitis vinifera.

Riassunto - Nuova segnalazione di parassitoidi di afidi su rose e vite in Turchia (Hem., Aphididae; Hym., Braconidae, Aphidiinae)

Viene segnalato per la prima volta in Turchia Aphidius eglanteriae Haliday come parassitoide di Chaetosiphon tetrarhodum/Rosa (Walker). Vengono fornite anche indicazioni sulla percentuale di parassitizzazione e la sua distribuzione nella provincia di Isparta. Ulteriori informazioni riguardano l'associazione tra Aphidius matricariae - Aphis illinoisensis - Vitis vinifera
\end{abstract}

Key words: Aphidius eglanteriae, Aphis illinoisensis, Aphidius matricariae, Chaetosiphon tetrarhodum, grapevine, roses

\section{Roses}

Turkey is one of the biggest producer of the rose oil and rose concrete in the world (Bayrak \& Akgül, 1994). Only chemical control is used to decrease harmful aphids quantity in Rose (Rosa damascena) plantations of Isparta Province. Chaetosiphon tetrarhodum (Walker), is one of main pest aphid of the Damask rose in Isparta Province, Turkey. This aphid causes weakness of plant by sucking activities and problems for producing great quantitities of honeydew, which is deposited on the leaves. Both these phenomena cause loss of yield of Damask rose flowers at the harvest time.

During our investigation we reared in the laboratory Aphidius eglanteriae Haliday, (1834), from the field sampled mummified C.tetrarhodum on Rosa damascena (Figure 1). It was found in three localities of Isparta Province: Isparta, Kuyucok and Sorkuncak. In July parasitism rate caused by attacking parasitic wasps to Ch. tetrarhodum was $4.35 \%$ in Kuyucok, $3.81 \%$ in Isparta and $0.92 \%$ in Sorkuncak. In September parasitism rate was $6.5 \%$ in Isparta. Low parasitism rate probably was caused by high temperature. 


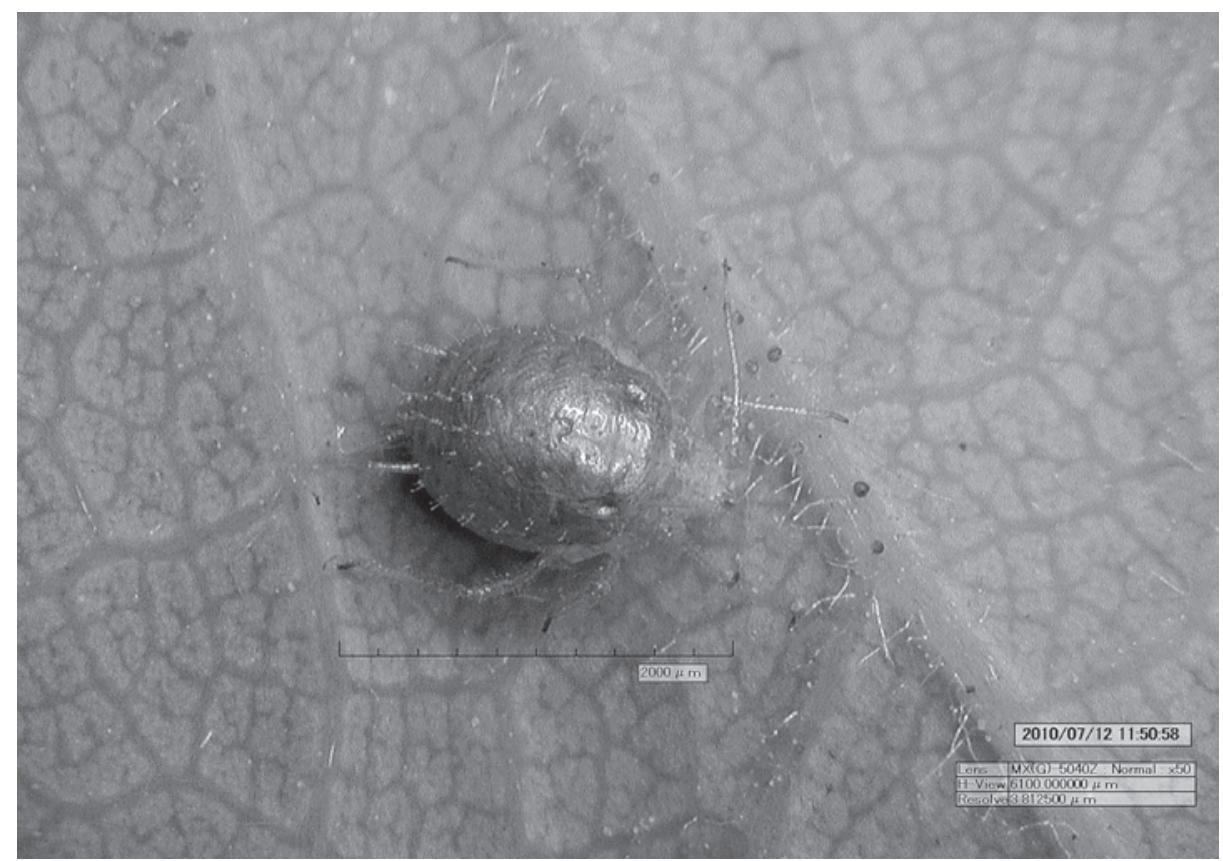

Fig. 1 - Mumified Chaetosiphon tetrarhodum on a leaf of Rosa damascena

This species is oligophagous and it attacks aphid species belonging to the genera Chaetosiphon and Longicaudus (Kavallieratos et al., 2004). It is distributed mainly in Europe (Starý, 1976; Kavallieratos et al., 2004). The association is new for Turkey (ElMali et al. 2004; Aslan and Karaca 2005; Tomanović et al., 2008).

A possibility of mass-rearing and release of this parasitoids in the rose fields should be further considered.

An over-all biodiversity of beneficial organisms in the biocenoses of oil-bearing rose was presented in Bulgaria (Balevski et al., 2008). However, merely Aphidius ervi Hal., Aphidius rosae Hal. and Ephedrus laevicollis (Thoms.) were listed as participating in the rose ecosystem. As no host aphid associations were included, we may presume an association between $A$. ervi and A. rosae to Macrosiphum rosae and E. laevicollis possibly to Chaetosiphon or Myzaphis (P. Stary, pers. comm.).

\section{Grapevine}

On 21 September 2010, we found Aphis illinoisensis (Shimer) on Vitis vinifera in Isparta Province for the first time (Barjadze et al., unpublished). There were big colonies of the grapevine aphids on the shoots and leaves of the grape. Through mechanical injury and honeydew production this aphid represents possibly an important economic threat to viticulture. 
One male specimen of Aphidius matricariae Haliday was reared from an aphid colony on 21 September 2010. This parasitoid was recorded from different Provinces of Turkey, including Isparta Province (El-Mali et al., 2004; Aslan and Karaca, 2005) but the presented association between Aphidius matricariae - Aphis illinoisensis - Vitis vinifera is recorded for the first time in the world. Further investigations will show whether A. matricariae is effective against grapevine aphids to use it in IPM. Also, it is recommendable to find further native enemies that attack A. illinoisensis or introduce them for controlling this invasive exotic grapevine aphid in Turkey.

\section{ACKNOWLEDGEMENTS}

We are grateful to Dr. Petr Starý (Institute of Entomology, Acad. Sci. of the Czech Republic) for help in parasitoid identification and valuable comments on our ms.

The project: "Aphids and their natural enemies associated with oil-bearing rose (Rosa damascena) in Isparta Province (Turkey)" has been fulfilled by the financial support of Research Fellowships for Foreign Citizens program (Code-2216) of TUBITAK.

\section{REFERENCES}

Aslan B., KARACA İ., 2005 - Fruit tree aphids and their natural enemies in Isparta Region, Turkey. J. Pest Sci. 78: 227-229.

BalevSKi N., Simova S., Draganova S., 2008 - Biodiversity of beneficial organisms (entomopathogens, predators and parasitoids) in the biocenoses of oil-bearing rose (Rosa damascena Mill.) in Bulgaria. Plant Sci. 45:115-122.

BAYRAK A., AKGÜl A., 1994 - Volatile oil composition of Turkish rose (Rosa damascena). J. Sci. Food Agr. 64: 441-448.

El-Mali M.U., Starý P., Sahbaz A., OzSermeci F., 2004 - A review of aphid parasitoids (Hym., Braconidae, Aphidiinae) of Turkey. Egypt. J. Biol. Pest Control 14: 355-370.

Kavallieratos N.G., Tomanović Ž., StarÝ P., Athanassiou Ch.G., Sarlis G.P., Petrović O., NiKETIĆ M., VERONIKI M.A., 2004 - A survey of aphids parasitoids (Hymenoptera: Braconidae: Aphidiinae) of Southeastern Europe and their aphid-plant associations. Appl. Entomol. Zool. 39: 527-563.

STARÝ P., 1976 - Aphid parasites (Hymenoptera, Aphidiidae) of the Mediterranean Area. Trans. Czech. Acad. Sci., ser. Math. Natur. Sci. 86: 1-95.

TOMANOVIĆ Ž., BEYARSLAN A., ERdoĞAN Ö., ŽIKIĆ V., 2008 - New records of aphids parasitoids (Hymenoptera, Braconidae, Aphidiinae) from Turkey. Period. Biol. 110: 335-338.

Shalva Barjadze, Nana GratiashVILI, Entomology and Biocontrol Research Centre of Ilia State University, Chavchavadze av. 31,0179, Tbilisi, Georgia

e-mail: shalva1980@yahoo.com.

İSMAIL KARACA, BÜLENT YAŞAR, Department of Plant Protection, Faculty of Agriculture, Süleyman Demirel University, 32260, Isparta, Turkey

Accepted 20 December 2010 